\title{
Chemical and Technological Evaluation of Some Varieties Naked Barley
}

\section{Abdelazim SAA*, Sohair T El-Hadidie and Masoud A Kamel}

\author{
Food Technology Research Institute (FTRI), Agriculture Research Center (ARC) Giza, Egypt
}

*Corresponding Author: Abdelazim SAA, Food Technology Research Institute (FTRI), Agriculture Research Center (ARC) Giza, Egypt.

Received: August 28, 2019; Published: October 14, 2019

\section{Abstract}

Chemical and technological of some varieties naked barley were Giza 130, Giza 131 and Giza 135 and their biscuit's was subjected to proximate composition and physical properties were evaluated. The physical properties as hectoliter, thousand grain weight and extraction rates of barley flour determined in naked barley varieties was 77.57 to $80.83 \mathrm{~g} / \mathrm{liter}, 31.41$ to $34.96 \mathrm{~g}$ and 66.18 to $68.94 \%$ respectively. The protein, fat, fiber, ash and total carbohydrates of the naked barley samples ranged between 11.92 to $12.45 \%$ and 0.79 to $2.05 \%, 0.41$ to $2.38 \%, 0.65$ to $2.03 \%$ and 81.32 to $86.23 \%$ respectively. Chemical composition of naked barley biscuits increased gradually by the increased percentage of naked barley flour at 25, 50,75 and 100\% compared control sample. Meanwhile that the total carbohydrate of naked barley biscuits decreased by additive naked barley flour compared control sample. The water holding and oil holding capacity increased gradually by the increased percentage of barley flour at 25, 50,75 and 100\%) compared control sample. Color measurements indicated that the lightness of biscuits color decreased by increasing barley flour varieties replacement. Physical properties of the biscuits ranged from 10.50 to 12.63 Weight (g), 5.6 diameter (mm), 0.5 to 0.6 thickness (mm), 8.0 to 11.20 expansion factor 11.3 to 13.3 Biscuit volume $\left(\mathrm{cm}^{3}\right)$ ranged from 0.92 to 1.24 Specific volume $(\mathrm{cm} 3) /(\mathrm{g})$ and 92.23 to 99.74 Hardness respectively. Sensory evaluated results obtained that the analysis of biscuits it can be concluded that replacement naked barley flour varieties had a positive effect on the characteristics of biscuits which reduce the ability of consumption in most of sensorial characteristics. While, the taste, odor and texture of biscuits improved in G135 by replacement of naked barley flour increase. The biscuits prepared by composite naked barley flour rich in nutrients than biscuits prepared with soft wheat flour. This showed that the naked barley flour is a good source of protein, ether extract, fiber and ash content. Hence it could be incorporated as nutritive ingredients in the production of healthy food products.

Keywords: Naked Barley; Biscuit; Proximate Composition; Sensory Properties; Physical Properties

\section{Introduction}

Barley (Hordeum vulgare $\mathrm{L}$.) is the fourth most important cereal crop in the world, after wheat, maize and rice, [1,2], ranking fourth among cereal grain production 38\% for maize 29\% for wheat, $20 \%$ for rice and $6 \%$ for barley [2]. It is also used as cattle feed in winter when the fodder deficit is large and feed prices are high [3]. Barley is an important food in many parts of the world such as North Africa, Near East, the Horn of Africa and Asia. It plays a key role not only as a source of food in the Maghreb, but also in the mountains of Ethiopia, Eritrea and Peru [4]. In North Africa, Near East, the Horn of Africa and Asia, mean annual consumption per person varies from 2 to $36 \mathrm{~kg}$ [5]. In Egypt, the average total annual area cultivated with barley grains are 87752 hectares which produced annually 117113 tons [6]. Barley differs greatly in chemical characteristics, due to genotype and environment and the interaction between the two. Wide ranges in chemical composition of barley have been reported [7]. Recommended that foods should contain at least $0.75 \mathrm{~g} /$ serving of oat or barley derived $\beta$-glucan for each serving portion to meet the health claim of $\beta$-glucan. Barley was presumably first used as human food but evolved primarily into a feed, malting and brewing grain due in part to the rise in prominence of wheat and rice, and there is renewed interest throughout the world in barley food because of its nutritional value. B-glucans (from barley, oat, and other cereals) has also been regarded as important functional ingredients in the cereal food industry [8]. Cereals are an excellent source of vitamin and minerals, including fat soluble vitamin E, which is an essential antioxidant. The cereal grains are an easy protein source as required by Recommended Daily Allowance (RDA) but unfortunately they lack the essential amino acid lysine and therefore they must not be used as the sole source of dietary protein [9]. The soluble $\beta$-glucans are present primarily in the endospermic cell walls of barley grain [10] which has been reported to be useful in regulating cholesterol and blood glucose levels [11]. Barley grain is considered to be an excellent source of many valuable nutrients, such as soluble and insoluble dietary fibers [12]. vitamin B complex, minerals, and phenolic compounds. The high nutritional value has been associated with $\beta$-glucans, the major 
fiber constituents in barley Keenan et al., [13], reduces glycemic index and blood cholesterol in the body [1] and obesity [14]. Health effects of $\beta$-glucans are suggested to lower plasma cholesterol, improving lipid metabolism, reducing glycaemic index and boosting the immune system [15-17], reducing the absorption of lipids and bile acid. Barley belongs among basic cereals, traditionally used for pearled barley, malt, and alcoholic drink production [10]. Barley can be successfully incorporated into a vast array of products such as different types of bread, Asian noodles, bars, muffins, biscuits and cookies [15]. Hull-less barley is a rich source of soluble and insoluble dietary fiber, providing beneficial non-starch polysaccharides, especially $\beta$-glucans Škrbić and Cvejanov [18] and Pejcz., et al. [19] Naked (hull-less) barley is a rich source of soluble (SDF) and insoluble (IDF) dietary fiber. It was proven that the high content of dietary fiber in whole grain plays a significant role in the health promoting effect of cereal based products and there is a strong connection between chronic diseases and obesity and the intake of dietary fiber [15]. Flour was one of the main raw materials for production of biscuits and white wheat flour was usually used. Types of wheat flour, which were used for making biscuits had low level of $9-10 \%$ proteins, low level of gluten and plastic properties. If flour with high level of gluten is used, final products will be greatly deformed during baking and the surface will be rough and covered with bubbles [20]. Nowadays, on the market there are biscuits and different baker's products made from mixing wheat flour and flour from other cereals such as: oat, rye, corn, buckwheat and barley flours etc. Lots of authors were presenting the positive effects of replacing barley flour with wheat flour on the qualitative properties of bread and biscuits [16]. Supplementing wheat flour by addition flours of different ceareals, aims to improve mineral, vitamin, protein or dietary fiber content and composition of bread [21]. Biscuits are convenient food products and the most popular bakery items consumed by nearly all levels of society in Egypt. Some of the reasons for such wide popularity are the low cost among other processed foods (affordable cost), good nutritional quality and availability in different varieties, varied taste, easy availability and longer shelf-life. Most of bakery products are used as a source for incorporation of different nutritionally rich ingredients for their diversification [22]. Biscuits were type of cookies with cereals as a basic component, and a rich source of protein and fat, carbohydrate, mineral and energy giving foods [23]. In the structure of biscuits there is large number of raw materials, different improvers and other additives, therefore they differ in: type, structure, mass, consistence, structure and technology of production $[24,25]$.

The main objectives of this investigation were to evaluate the chemical and technological evaluation of G130,G131 and G135 varieties naked barley and make biscuits from naked barley flour. The produced biscuits were also evaluated for their nutritional, physical and sensory characteristics and compared to wheat biscuit as a superior quality biscuit and reduce wheat flour shortages.

\section{Materials and Methods}

Materials

Naked barley (Hordeum vulgare variety) Giza(G) 130, Giza 131 and Giza 135(G130,G131 and G135) was obtained from the barley Research Department and wheat (Tritucm astivum) was obtained from the wheat Research Depart., Field Research Institute, Agricultural Research Center, Giza, Egypt. The collected seeds were cleaned of foreign materials and stored at room temperature $(25$ $\pm 2^{\circ} \mathrm{C}$ ). Till chemical analysis. All raw material and the used in this study were obtained from local marked, Giza, Egypt, used chemical evaluation: all chemicals used in this study were analytical grade.

\section{Methods}

Physical properties of the naked barley grains

The weight of 1000 seeds W1000 was determined by weighing 1000 seeds in triplicate and 1000 grain mass, 1000 grains randomly selected for the bulk were averaged. The mass of grain was measured using an electronic balance to an accuracy of $0.001 \mathrm{~g}$. Hectolitre weight (HLW) was determined using a Dickey-John GAC2100 where $500 \mathrm{~g}$ of naked barley was poured into the top hopper. This method was applied according to Gloria [26].

\section{Milling naked barley seeds varieties}

Egyptian naked barley varieties were cleaned and conditioned at approximately $14 \%$ moisture content. The conditioned wheat varieties were milled using Qudrumat Senior Laboratory Mill to give of the flour according to [27].

Functional properties of composite flour of naked barley varieties

\section{Water holding capacity (WHC)}

Water Holding Capacity (WHC) was determined according to Heywood., et al. [28] and Traynham., et al. [29] but with some modifications. One gram of flour was weighed in preweighed $30 \mathrm{~mL}$ plastic centrifuge tubes. For each sample, 10 $\mathrm{ml}$ of distilled water was added and well mixed with the sample. Samples stood at room temperature $\left(22 \pm 2^{\circ} \mathrm{C}\right)$ for 30

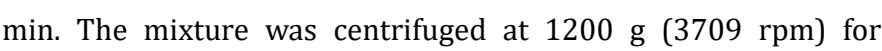
30 min. Just after centrifugation, the supernatant was carefully decanted and the new mass of the sample was recorded.

WHC (g water/g powder) was calculated as:

WHC $=$ Total water mass $/$ Dry matter mass

\section{Oil holding capacity (OHC)}

Oil Holding Capacity (OHC) was determined according to $\mathrm{Ni}$ dhina and Muthukumar [30] with slight modifications. One gram of 
flour (W0) was weighed and added to $10 \mathrm{~g}$ of sunflower oil within a 50 -mL centrifuge tube, and then mixed for $10 \mathrm{~s}$ using a Vortex mixer every $5 \mathrm{~min}$ for $30 \mathrm{~min}$. The samples were then centrifuged for $15 \mathrm{~min}$ at $1,000 \times \mathrm{g}$ at room temperature. The supernatant was removed and the pellet was weighed and recorded as W1. The OHC was calculated using following equation and reported as $\mathrm{g}$ oil/g flour on a dry basis.

$\mathrm{OHC}=\frac{\mathrm{W}_{1}-\mathrm{W}_{0}}{\mathrm{~W}_{0}}$
Preparation of wheat and naked barley biscuits

Biscuits samples were prepared according to the standard procedure for semi hard sweet biscuits (peti-pier type) of Bisco Misr Comp. Cairo, Egypt (Table 1). Biscuit was prepared by partially replacing soft wheat flour (SWF) with 25, 50, 75and100\% of barley flour (BF).The percent increase in replacement was done till they were palataptalty without giving off flavors. The ratio were (wheat flour: barley flour) 100: 00, 75: 25, 50: 50, 25: 75 and 00:100\%.

Table 1: The basic formula of biscuits produced by naked barley varieties (G 130, G 131 and G 135).

\begin{tabular}{|c|c|c|c|c|c|c|c|c|c|c|c|c|c|c|}
\hline \multirow{2}{*}{\multicolumn{2}{|c|}{$\begin{array}{c}\text { Treat } \\
\text { Materials }\end{array}$}} & \multirow{3}{*}{ Control } & \multicolumn{4}{|c|}{ G 130} & \multicolumn{4}{|c|}{ G 131} & \multicolumn{4}{|c|}{ G135 } \\
\hline & & & \multirow[t]{2}{*}{25} & \multirow[t]{2}{*}{50} & \multirow[t]{2}{*}{75} & \multirow{2}{*}{$\frac{100}{*}$} & \multirow[t]{2}{*}{25} & \multirow[t]{2}{*}{$\mathbf{5 0}$} & \multirow[t]{2}{*}{75} & \multirow{2}{*}{$\frac{100}{*}$} & \multirow[t]{2}{*}{25} & \multirow[t]{2}{*}{50} & \multirow[t]{2}{*}{75} & \multirow{2}{*}{$\frac{100}{*}$} \\
\hline Wheat flour & $0 \%$ & & & & & & & & & & & & & \\
\hline $72 \%$ & $25 \%$ & & & & $*$ & & & & $*$ & & & & $*$ & \\
\hline & $50 \%$ & & & $*$ & & & & $*$ & & & & $*$ & & \\
\hline & $75 \%$ & & $*$ & & & & $*$ & & & & $*$ & & & \\
\hline & $100 \%$ & $*$ & & & & & & & & & & & & \\
\hline \multicolumn{2}{|l|}{ Sugar (30g) } & $*$ & $*$ & $*$ & $*$ & $*$ & $*$ & $*$ & $*$ & $*$ & $*$ & $*$ & $*$ & $*$ \\
\hline \multicolumn{2}{|c|}{ Butter milk (15g) } & $*$ & $*$ & $*$ & $*$ & $*$ & $*$ & $*$ & $*$ & $*$ & $*$ & $*$ & $*$ & $*$ \\
\hline \multicolumn{2}{|c|}{ Skimmed milk (1g) } & $*$ & $*$ & $*$ & $*$ & $*$ & $*$ & $*$ & $*$ & $*$ & $*$ & $*$ & $*$ & $*$ \\
\hline \multicolumn{2}{|c|}{ Amon. Bica (0.66g) } & $*$ & $*$ & $*$ & $*$ & $*$ & $*$ & $*$ & $*$ & $*$ & $*$ & $*$ & $*$ & $*$ \\
\hline \multicolumn{2}{|c|}{ Sod. bica (0.33g) } & $*$ & $*$ & $*$ & $*$ & $*$ & $*$ & $*$ & $*$ & $*$ & $*$ & $*$ & $*$ & $*$ \\
\hline \multicolumn{2}{|c|}{ Fresh w. egg (24g) } & $*$ & $*$ & $*$ & $*$ & $*$ & $*$ & $*$ & $*$ & $*$ & $*$ & $*$ & $*$ & $*$ \\
\hline \multicolumn{2}{|c|}{ Vanillia (0.30g) } & $*$ & $*$ & $*$ & $*$ & $*$ & $*$ & $*$ & $*$ & $*$ & $*$ & $*$ & $*$ & $*$ \\
\hline
\end{tabular}

Physical characteristics of biscuit made from naked barley

- Hardness ( $\mathbf{N}$ ): Hardness was the maximum load, expressed in $\mathrm{kg}$, applied to the samples during the first compression. Hardness was the force required to bite completely through the sample when placed between molars [27].

- Diameter (mm): The diameter (D) was measured by placing six biscuits edge to edge to get an average diameter in millimeters. Thickness, expansion factor $(\mathrm{D} / \mathrm{T})$, weight $(\mathrm{g})$ and volume $(\mathrm{cm} 3)$ of biscuit made from naked barley flour was measured according to standard methods [27].

Determination of water activity $\left(a_{\mathrm{w}}\right)$

The water activity was measured with a Rotronic (model Hygrolab3 made in Switzerland). The ground sample of biscuits was filled with the plastic cups approach the top and the Hygroplam probe was inserted in these cups. After almost three to four minutes the display was shown the water activity reading, along with temperature [31].

\section{Color measurement of biscuits samples}

Measuring the color of the biscuits in the CIE L*a*b* sys $\neg$ tem by using a colorimeter (Konica Minolta Chroma Meter CR-400, Japan) and calculations to determine the change of color were made according to the method described from Budžaki., et al. [32].
Chemical composition of wheat and naked barley biscuit

Moisture, ash, ether extract, fiber and crude protein were determined according to the methods described in the A.O.A.C. [33]. Moreover, total carbohydrates were determined by difference. Energy value (Cal./100gm) of the cooked samples was calculated using the following equation: Energy value $=[(\%$ of carbohydrate $x$ $4)+(\%$ of protein $x 4)+(\%$ of fat $x 9)]$. All results were recorded as the mean value of 3 replicates.

\section{Sensory evaluation of samples}

The biscuits samples were judged by ten trained panelists in Field Crop Technoloy Research, Research Dept., and Bread and Pasty, Research Dept., Food Technology Research Institute, Agric. Res. Center, Giza. The biscuits sensorial tested for general appearance 20 , taste 20 , odor 20 , color 20 , texture 20 and overall acceptability 100 degrees according to Smith [34].

\section{Statistical analysis}

The obtained data were exposed to analysis of variance. Duncan's multiple range tests at $(\mathrm{P} \leq 0.05)$ level was used to compare between means. The analysis was carried out using the PRO ANOVA procedure of the Statistical Analysis System [35].

\section{Results and Discussion}

Physical properties of grain naked barley varieties

The physical properties as hectoliter and thousand grain weight as well as extraction rates of barley determined in naked barley va- 
rieties and the obtained data in figure 1 The hectoliter and thousand grain weight were higher in G135 (80.83a \pm 0.66 and 34.66a \pm $0.21 \mathrm{~g}$ ) followed by G131(78.40a \pm 0.54 and $34.66 \mathrm{a} \pm 0.21 \mathrm{~g})$. While, G130 showed the lowest values of hectoliter and thousand grain weight $(77.57 \mathrm{a} \pm 0.56$ and $31.41 \mathrm{~b} \pm 0.25 \mathrm{~g})$. The extraction rate data were showed in figure 2 . it could be seen that the extraction rates had higher in G135 (68.94a \pm 0.25 and G131 (67. 34b \pm 0.12 ) than G 130 (66. 18c \pm 0.5$)$. The results showed that the a positive correlation between hectoliter, thousand grain weight and extraction rates flour of naked barley varieties. While, reversible correlation between hectoliter and the extraction rates of flour.

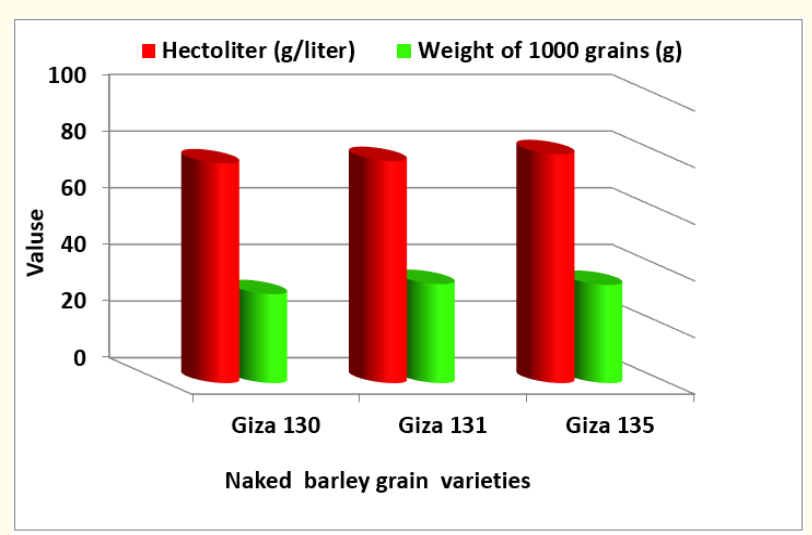

Figure 1: Physical properties of naked barley grain varieties.

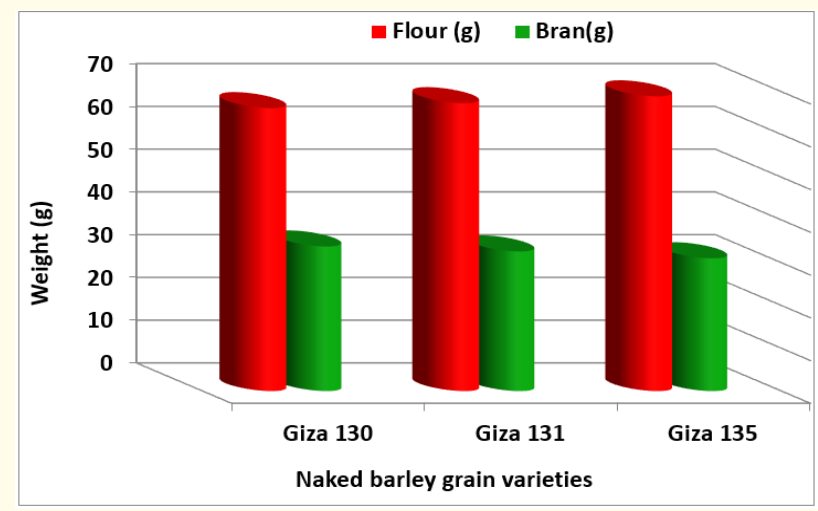

Figure 2: Extraction percentage (\%) rates of naked barley varieties.

Chemical composition of whole naked barley varieties and soft wheat flour $72 \%$ ext.rate

The chemical composition of whole meal naked barley varieties and soft wheat flour $72 \%$ ext.rate illustrated. The moisture content ranged between $8.51 \pm 0.10$ to $7.32 \pm 0.13 \%$ in naked barley flour varieties. While, the moisture content in soft wheat flour $72 \%$ ex was $11.18 \mathrm{a} \pm 0.11 \%$ of dry weight. The protein content and ether extract in G135 variety where the higher content than G 131 and G130 variety $12.45 a \pm 0.12$ than G13111.98b \pm 0.11 and G13011.86b \pm 0.11 on dry weight) respectively. While the ether extract of naked barley flour G135 had the highest values than G131 and G $130(1.86 \mathrm{a} \pm 0.01$ than $1.82 \mathrm{ab} \pm 0.12$ and $1.78 \mathrm{~b} \pm 0.15)$ respec- tively. The data showed that the fiber and ash contents of G130, G131 and G135 was $(2.38 \mathrm{a} \pm 0.01,2.41 \mathrm{a} \pm 0.03 \mathrm{and} 2.34 \pm 0.02)$ and $(1.83 a \pm 0.02,1.69 a \pm 0.02 a n d 2.03 a \pm 0.01)$ The results showed that the calculated total carbohydrate in figure 3 . The highest content of total carbohydrate in barley varieties in Giza130 was (82.15b $\pm 1.11)$ than G131 $(82.10 b \pm 1.22)$ and G135 $(81.32 \mathrm{c} \pm 1.25)$. Soft wheat flour contained a moderate amount of protein, ether extract, fiber and ash content $(11.92 b \pm 0.11,0.79 c \pm 0.01,0.41 b \pm 0.01$ and $0.65 \mathrm{~b} \pm 0.02 \%$ ) and high total carbohydrate (86.23a \pm 1.33 ). Barley, oats, rice, corn or wheat have lower quality proteins and higher levels of energy, calcium, phosphorus, iron, fiber and B vitamins than quinoa seeds [36]. The results of chemical composition of wheat flour are in close agreement with those obtained by Hassan., et al. [37], Lopez [38], Abdel-Gawad., et al. [39] and Maray., et al. [40].

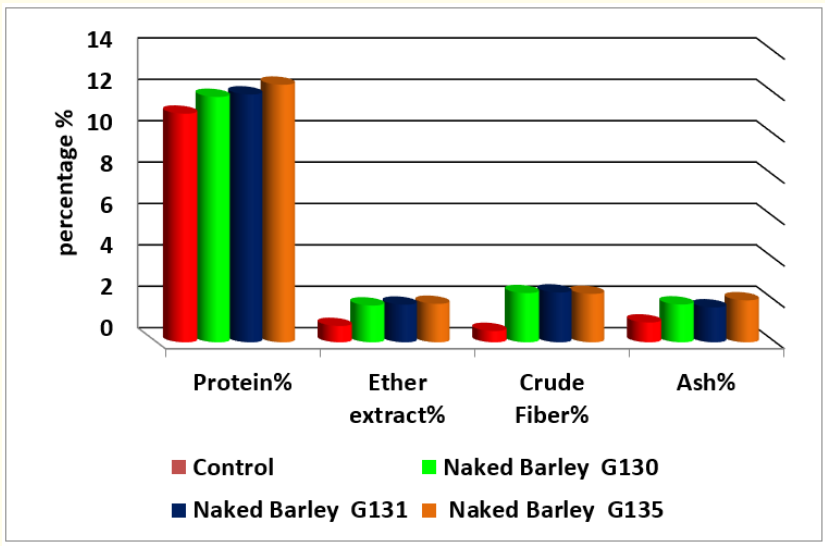

Figure 3: Chemical composition of wheat flour and naked barley grain varieties.

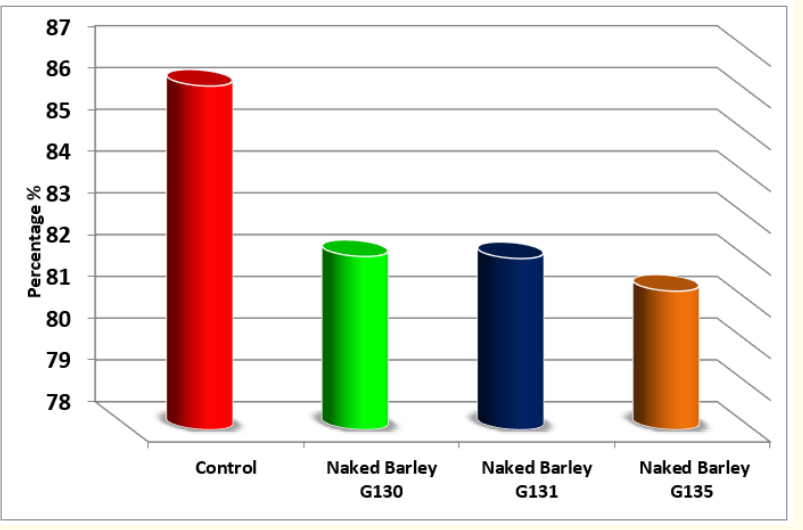

Figure 4: Total carbohydrate of wheat flour and naked barley grain varieties.

Functional properties of composite flour of naked barley varieties

Water and oil holding capacity

Functional properties water holding capacity, (WHC) and oil holding capacity, OHC of flour for naked barley varieties replace- 
ment at 25, 50.75 and $100 \%$ are presented in figure 4, The Water holding capacity and oil holding capacity are essential functional properties of protein which depend on pore size and the charges on the protein molecules. High WHC determines the hydrophilic nature and high hydrogen bonding of protein molecules [41]. From which, it could be indicated that the water holding capacity increased gradually by the increased percentage of naked barley at $25,50.75$ and $100 \%$ ) compared to control sample (wheat flour $72 \%$ ex.). The water holding capacity of capacity of composite flour for naked barley varieties G130, G131 and G135 replacement at levels 25 had increased values than control $(1.11,1.12$ and 1.13 than $0.89 \mathrm{~g} / \mathrm{g}$ ) respectively. The increment was high on the high percentage (100\%) of barley varieties replacement in G130, G131 and G135 (1.43, 1.45 and $1.46 \mathrm{ml} / \mathrm{g}$ ) compared $0.89 \mathrm{~g} / \mathrm{g}$ respectively. The results showed that flour for naked barley variety G135 replacement at 25, 50,75 and 100\% had the highest WHC value $(1.13,1.21,1.29$ and $1.46 \mathrm{~g} / \mathrm{g}$ flour sample followed by G131 $(1.12,1.2,1.33$ and $1.45 \mathrm{~g} / \mathrm{g}$ flour sample) and the G130 had the lowest values (1.11, 1.19, 1.33 and 1.4g/g flour sample). Higher values of water holding capacity seen for the hull-less barley relative to the chickpeas are thought to be associated with its higher amount of starches and more gelatinized starch as well as the betaglucan that can absorb water [42]. A range of Water absorption capacity from 149.1 to $471.5 \%$ is considered favorable for the preparation of viscous foods such as soups, gravies and bakery products [43]. Water absorption capacity is a critical function of protein in various food products like Soups, dough and baked products [44]. Barley proteins are dominated by prolamin proteins 33 - 55\% of total proteins [45].

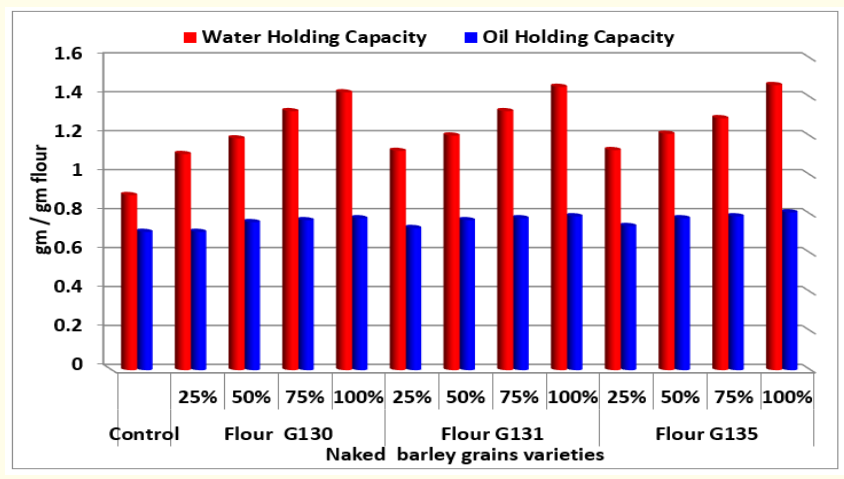

Figure 5: The water holding capacity and oil holding capacity of composite flour for naked barley varieties.

\section{Oil holding capacity}

The oil holding capacity (OHC) of flour for naked barley varieties replacement at 25, 50.75 and 100\% are presented in fig. (5). The oil holding capacity of composite flour for naked barley varieties G130,G131 and G135 replacement at 25to100\% ranged be- tween 0.71 to $0.78,0.73$ to 0.79 and 0.74 to $0.81 \mathrm{~g} / \mathrm{g}$ substitution as compared with control $0.71 \mathrm{~g} / \mathrm{g}$. It could be observed that the oil holding capacity values of composite flour for naked barley varieties replacement (at 25, 50,75 and 100\%) had slight increase compared wheat flour as control samples. The percentages of increase were $0.71,0.76,0.77$ and $0.78 \mathrm{~g} / \mathrm{g}$ at $25,50,75$ and $100 \%$ barley replacement with G130, respectively. While, OHC values of G131 at different percentage replacement barley flour the increased were $0.73,0.77,0.78$ and $0.79 \mathrm{~g} / \mathrm{g}$ respectively. The composite flour for naked barley variety G135 replacement (at 25, 50,75 and 100\%) had values $0.74,0.78,0.79$ and $0.81 \mathrm{~g} / \mathrm{g}$, High OHC indicated that the enhanced hydrophobic character of proteins in the flours. OHC is exhibited by the proteins in the flour, which physically bind to fat by capillary attraction. These proteins expose more non-polar amino acids in the fat and enhance hydrophobicity as a result of which flours absorb oil. OHC plays a significant role in ground meat formulations like sausages and to increase the shelf life of meat products [46].

The chemical composition of biscuits made from wheat flour $72 \%$ ex and naked barely grains varieties

The results of chemical composition of biscuits made from soft wheat flour and replacement naked barley varieties are shown in table 2. The results showed an increase in protein, ether extract, fiber and ash content of biscuits prepared by naked barley than biscuits prepared with wheat flour as control samples. The protein content in biscuits prepared by four level replacement of barley flour varieties ranged between 11.38 to 11.71 at $25 \%$, ranged between 11.97 to 12.14 at $50 \%, 12.04$ to 12.18 at $75 \%$ and between 12.11 to 12.27 at $100 \%$ replacement as compared with biscuits control $11.05 \%$. The ether extract increased gradually in biscuits prepared by different replacement of barley flour. The ether extract in biscuits replacement by G 135 was higher in different substitutions of barley flour than other biscuits. The results found high in both fiber and ash content which had high in biscuits produced by different naked barley varieties replacement compared the control. The fiber and ash content were $(1.17,1.13 \%),(1.20,1.09 \%)$ and $(1.19,1.09 \%)$ in biscuits prepared by $25 \%$ barley flour of G130, G131 and G135, respectively. The highest percentage of replacement naked barley varieties had a higher contents of fiber and ash which were $(2.83$, $1,56)$ in G130, $(2.87,1.51)$ in G 131 and $(2.89,1.47)$ in G135\%. It could be noticed that the chemical composition (protein, fiber and ash) increased gradually by the increased percentage of naked barley at 25, 50.75 and $100 \%$ compared to control sample. Meanwhile that the total carbohydrate decreased by addition naked barley flour compared to control sample. The biscuits prepared by composite naked barley flour richer in nutrients than biscuits prepared with soft wheat flour This showed that the naked barley flour is a good source of protein, ether extract, fiber and ash content. Hence it could be incorporated as nutritive ingredients in the production of healthy food products. Our results agree with Hassan., et al. [37]. 
Table 2: The chemical composition of biscuits made by different replacement of naked barley flour varieties.

\begin{tabular}{|c|c|c|c|c|c|c|c|}
\hline \multicolumn{2}{|c|}{$\begin{array}{c}\text { Naked barley } \\
\text { varieties }\end{array}$} & Moisture \% & Protein \% & Ether extract \% & Fiber \% & Ash \% & \% Total carbohydrate \\
\hline \multicolumn{2}{|c|}{ Control } & $3.79^{\mathrm{c}} \pm 0.01$ & $11.05^{\mathrm{b}} \pm 0.03$ & $12.51^{\mathrm{d}} \pm 0.01$ & $0.55^{\mathrm{c}} \pm 0.02$ & $0.96^{\mathrm{c}} \pm 0.02$ & $74.93^{\mathrm{a}} \pm 0.5$ \\
\hline \multirow{3}{*}{$\mathrm{G} 130$} & $25 \%$ & $4.0^{\mathrm{c}} \pm 0.02$ & $11.38^{\mathrm{ab}} \pm 0.01$ & $12.66^{\mathrm{cd}} \pm 0.05$ & $1.17^{\mathrm{b}} \pm 0.01$ & $1.13^{\mathrm{abc}} \pm 0.01$ & $73.66^{\mathrm{ab}} \pm 0.55$ \\
\cline { 2 - 8 } & $50 \%$ & $4.04^{\mathrm{ab}} \pm 0.1$ & $11.97^{\mathrm{ab}} \pm 0.01$ & $13.02^{\mathrm{abc}} \pm 0.03$ & $1.79^{\mathrm{ab}} \pm 0.01$ & $1.29^{\mathrm{ab}} \pm 0.01$ & $71.9^{\mathrm{b}} \pm 0.23$ \\
\cline { 2 - 8 } & $75 \%$ & $4.39^{\mathrm{ab}} \pm 0.03$ & $12.04^{\mathrm{ab}} \pm 0.01$ & $13.48^{\mathrm{ab}} \pm 0.33$ & $2.25^{\mathrm{a}} \pm 0.01$ & $1.47^{\mathrm{a}} \pm 0.03$ & $70.76^{\mathrm{c}} \pm 0.25$ \\
\cline { 2 - 8 } & $100 \%$ & $4.71^{\mathrm{ab}} \pm 0.05$ & $12.11^{\mathrm{ab}} \pm 0.31$ & $13.71^{\mathrm{bc}} \pm 0.12$ & $2.83^{\mathrm{ab}} \pm 0.01$ & $1.56^{\mathrm{ab}} \pm 0.01$ & $69.79^{\mathrm{c}} \pm 0.21$ \\
\hline \multirow{3}{*}{$\mathrm{G} 131$} & $25 \%$ & $4.50^{\mathrm{a}} \pm 0.02$ & $11.50^{\mathrm{ab}} \pm 0.11$ & $12.82^{\mathrm{cd}} \pm 0.06$ & $1.20^{\mathrm{b}} \pm 0.11$ & $1.09^{\mathrm{bc}} \pm 0.05$ & $73.39^{\mathrm{a}} \pm 0.33$ \\
\cline { 2 - 8 } & $50 \%$ & $4.53^{\mathrm{ab}} \pm 0.04$ & $12.12^{\mathrm{a}} \pm 0.11$ & $13.11^{\mathrm{abc}} \pm 0.07$ & $1.89^{\mathrm{ab}} \pm 0.21$ & $1.25^{\mathrm{ab}} \pm 0.03$ & $71.63^{\mathrm{bc}} \pm 0.27$ \\
\cline { 2 - 8 } & $75 \%$ & $4.74^{\mathrm{a}} \pm 0.06$ & $12.16^{\mathrm{ab}} \pm 0.21$ & $13.51^{\mathrm{ab}} \pm 0.22$ & $2.32^{\mathrm{a}} \pm 0.11$ & $1.39^{\mathrm{ab}} \pm 0.04$ & $70.62^{\mathrm{c}} \pm 0.33$ \\
\cline { 2 - 8 } & $100 \%$ & $4.88^{\mathrm{a}} \pm 0.05$ & $12.25^{\mathrm{ab}} \pm 0.11$ & $13.71^{\mathrm{bc}} \pm 0.26$ & $2.87^{\mathrm{a}} \pm 0.21$ & $1.51^{\mathrm{abc}} \pm 0.02$ & $69.66^{\mathrm{c}} \pm 0.24$ \\
\hline \multirow{3}{*}{ G135 } & $25 \%$ & $4.37^{\mathrm{ab}} \pm 0.03$ & $11.71^{\mathrm{ab}} \pm 0.22$ & $12.72^{\mathrm{cd}} \pm 0.28$ & $1.19^{\mathrm{b}} \pm 0.33$ & $1.09^{\mathrm{abc}} \pm 0.1$ & $73.29^{\mathrm{b}} \pm 0.20$ \\
\cline { 2 - 8 } & $50 \%$ & $4.74^{\mathrm{a}} \pm 0.11$ & $12.14^{\mathrm{ab}} \pm 0.23$ & $13.21^{\mathrm{bc}} \pm 0.23$ & $1.85^{\mathrm{ab}} \pm 0.21$ & $1.28^{\mathrm{ab}} \pm 0.02$ & $71.52^{\mathrm{b}} \pm 0.44$ \\
\cline { 2 - 8 } & $75 \%$ & $4.80^{\mathrm{a}} \pm 0.21$ & $12.18^{\mathrm{a}} \pm 0.2$ & $13.50^{\mathrm{ab}} \pm 0.11$ & $2.28^{\mathrm{a}} \pm 0.22$ & $1.43^{\mathrm{ab}} \pm 0.01$ & $70.61^{\mathrm{c}} \pm 0.11$ \\
\cline { 2 - 8 } & $100 \%$ & $4.80^{\mathrm{a}} \pm 0.25$ & $12.27^{\mathrm{ab}} \pm 0.11$ & $13.82^{\mathrm{a}} \pm 0.05$ & $2.89^{\mathrm{a}} \pm 0.11$ & $1.47^{\mathrm{ab}} \pm 0.11$ & $69.55^{\mathrm{c}} \pm 0.45$ \\
\hline
\end{tabular}

\section{Physical properties of produced biscuits}

The Weight (g), diameter ( $\mathrm{mm})$, thickness $(\mathrm{mm})$, expansion factor, biscuit volume $\left(\mathrm{cm}^{3}\right)$, Specific volume $\left(\mathrm{cm}^{3}\right) /(\mathrm{g})$, and Hardness $(\mathrm{N})$ as physical properties of biscuits prepared by different replacement of naked barley varieties present in table 3 . The weight of biscuits increased with increasing the percentage of naked barley varieties. The increase of weight in G135 was higher than in G130 followed by G131.The expansion factor of biscuits was high in both G135 followed by G130 and higher than control biscuits (8.14). While, the expansion factor in biscuits prepared with different replacement of G 131 was lower than control. The volume decreased in biscuits prepared with G135 rapidly with the percentage replacement of naked barley increased. The degradation G 135 was higher than the decrease in G 131 and G130 as compared with control. The specific volume of biscuits samples was lower than control. The lower specific volume found in G131 followed by G130 and G135. Although, the thickness of biscuits in G135 was thin, the hardness in the same samples recorded higher hardness than other biscuits samples in G 131 and G 130 and lower than the control sample. The hardness decreased by the percentage naked barley replacement increased. The same data of the results of water activity of biscuits made from soft wheat flour and naked barley varieties are shown in table 4 . The water activity of biscuits by different percentage of barley varieties had lower compared with control sample varieties. The water activity in biscuits replacement by different replacement of G 130 and G 135 was similar and lower than G 131. The results agree with Hassan., et al. [37].

\section{Biscuits color measurements}

Color is one of the most important quality attributes of bakery products. The Hunter color parameters L)Lightness), a (redness/ greenness) and b (yellowness/blueness) are widely used to describe color changes of food materials. Preferred colors are those closest to the original color of samples. Color measurements of biscuits made from the different replacement naked barley flour varieties and the results are tabulated in table 5 . The results indicated that the significantly increased in lightness $\left(\mathrm{L}^{*}\right)$ values of the samples, Data indicated that the lightness of biscuit color decreased by increasing barley flour varieties replacement increased. Where G135 recorded the lower value, followed by G131 than G130. While, the (b) values of biscuits, increase gradually by the replacement of barley flour increased in all varieties. The (b) values of biscuits replacement by naked barley flour G135 found higher than G131 and G130 at 100\%. Results agreement with Hassan., et al. [37].

\section{The sensory characteristics of produced biscuits}

The sensory characteristics of biscuits prepared by different substitution of barley varieties present in table 6 . The color and appearance characteristic values decreased in all biscuits prepared by different replacement naked barley flour varieties. The lower decrease values of color and appearance found in G 131 followed by $\mathrm{G} 135$ then $\mathrm{G} 130$.Also the taste and odor values were decreased regularly in both biscuits varieties G 130 and G 131 with increased replacement of naked barley flour up to $100 \%$. Whereas, the replacement of naked barley flour G135 showed increases in taste, 
Table 3: The physical properties of biscuits prepared by different substitution of new barley flour varieties.

\begin{tabular}{|c|c|c|c|c|c|c|c|c|}
\hline \multicolumn{2}{|c|}{ Samples } & $W(g)$ & $\mathrm{D}(\mathrm{mm})$ & $\mathrm{T}(\mathrm{mm})$ & E.F (D/T) & B. $V\left(\mathrm{~cm}^{3}\right)$ & $\mathrm{SV}\left(\mathrm{cm}^{3}\right) /(\mathrm{g})$ & $H(N)$ \\
\hline \multicolumn{2}{|c|}{ control } & $10.28 \pm 1.1$ & $5.6 \pm 0.1$ & $0.7 \pm 0.01$ & $8.14 \pm 0.2$ & $15.0 \pm 0.11$ & $1.45 \pm 0.01$ & $103.49 \pm 5.5$ \\
\hline \multirow[t]{4}{*}{ Giza 130} & $25 \%$ & $10.50 \pm 1.5$ & $5.6 \pm 0.2$ & $0.6 \pm 0.1$ & $9.33 \pm 0.5$ & $13.3 \pm 0.22$ & $1.26 \pm 0.03$ & $98.76 \pm 3.3$ \\
\hline & $50 \%$ & $10.70 \pm 1.3$ & $5.6 \pm 0.2$ & $0.6 \pm 0.01$ & $9.33 \pm 0.2$ & $13.3 \pm 0.45$ & $1.24 \pm 0.05$ & $98.07 \pm 5.3$ \\
\hline & $75 \%$ & $10.90 \pm 1.1$ & $5.6 \pm 0.4$ & $0.6 \pm 0.02$ & $9.33 \pm 0.33$ & $12.6 \pm 0.55$ & $1.16 \pm 0.11$ & $94.24 \pm 6.5$ \\
\hline & $100 \%$ & $11.18 \pm 1.2$ & $5.6 \pm 0.6$ & $0.6 \pm 0.01$ & $9.33 \pm 0.5$ & $11.6 \pm 0.22$ & $1.04 \pm 0.02$ & $92.23 \pm 2.2$ \\
\hline \multirow[t]{4}{*}{ Giza 131} & $25 \%$ & $10.80 \pm 1.4$ & $5.6 \pm 0.1$ & $0.7 \pm 0.1$ & $8.0 \pm 0.1$ & $13.3 \pm 0.5$ & $1.23 \pm 0.03$ & $98.26 \pm 5.5$ \\
\hline & $50 \%$ & $11.61 \pm 1.2$ & $5.6 \pm 0.1$ & $0.7 \pm 0.01$ & $8.0 \pm 0.5$ & $12.6 \pm 1.1$ & $1.09 \pm 0.22$ & $97.98 \pm 4.4$ \\
\hline & $75 \%$ & $12.01 \pm 1.1$ & $5.6 \pm 0.2$ & $0.7 \pm 0.02$ & $8.0 \pm 0.22$ & $12.3 \pm 2.2$ & $1.02 \pm 0.04$ & $96.09 \pm 1.2$ \\
\hline & $100 \%$ & $12.21 \pm 1.1$ & $5.6 \pm 0.3$ & $0.7 \pm 0.1$ & $8.0 \pm 0.11$ & $11.3 \pm 1.1$ & $0.92 \pm 0.0$ & $94.81 \pm 1.3$ \\
\hline \multirow[t]{4}{*}{ Giza 135} & $25 \%$ & $10.91 \pm 1.3$ & $5.6 \pm 0.5$ & $0.5 \pm 0.02$ & $9.33 \pm 0.22$ & $13.0 \pm 2.1$ & $1.31 \pm 0.01$ & $99.91 \pm 2.2$ \\
\hline & $50 \%$ & $11.25 \pm 1.1$ & $5.6 \pm 0.4$ & $0.5 \pm 0.01$ & $11.2 \pm 0.22$ & $12.6 \pm 0.5$ & $1.23 \pm 0.02$ & $99.74 \pm 3.3$ \\
\hline & $75 \%$ & $12.57 \pm 1.0$ & $5.6 \pm 0.2$ & $0.5 \pm 0.0$ & $11.2 \pm 0.11$ & $11.6 \pm 0.4$ & $1.10 \pm 0.1$ & $98.35 \pm 3.5$ \\
\hline & $100 \%$ & $12.63 \pm 1.5$ & $5.6 \pm 0.2$ & $0.5 \pm 0.01$ & $11.2 \pm 0.14$ & $11.3 \pm 0.6$ & $1.06 \pm 0.04$ & $97.06 \pm 5.5$ \\
\hline
\end{tabular}

Weight: W(g); Diameter: D (mm); Thickness: T (mm); Expansion Factor: (D/T); Biscuit Volume: B. V( $\left.\mathrm{cm}^{3}\right)$; Specific Volume: S V $\left(\mathrm{cm}^{3}\right) /(\mathrm{g})$; and Hardness(N): H (N).

Table 4: The water activity $\left(a_{\mathrm{w}}\right)$ of biscuits prepared by different substitution of naked barley flour varieties.

\begin{tabular}{|c|c|c|c|}
\hline \multicolumn{2}{|c|}{ Samples } & $\boldsymbol{a}_{\mathbf{w}}$ & $\mathbf{C}^{\circ}$ \\
\hline \multicolumn{2}{|c|}{ Control } & $\mathbf{0 . 3 2 4} \pm \mathbf{0 . 0 0 2}$ & $\mathbf{2 6 . 0 0}$ \\
\hline Giza 130 & $25 \%$ & $0.308 \pm 0.003$ & 26.04 \\
\cline { 2 - 4 } & $50 \%$ & $0.290 \pm 0.000$ & 26.10 \\
\cline { 2 - 4 } & $75 \%$ & $0.286 \pm 0.004$ & 26.07 \\
\cline { 2 - 4 } & $100 \%$ & $0.283 \pm 0.002$ & 26.07 \\
\hline Giza 131 & $25 \%$ & $0.314 \pm 0.003$ & 26.14 \\
\cline { 2 - 4 } & $50 \%$ & $0.303 \pm 0.002$ & 26.16 \\
\cline { 2 - 4 } & $75 \%$ & $0.301 \pm 0.000$ & 26.17 \\
\cline { 2 - 4 } & $100 \%$ & $0.289 \pm 0.005$ & 26.25 \\
\hline Giza 135 & $25 \%$ & $0.297 \pm 0.003$ & 26.28 \\
\cline { 2 - 4 } & $50 \%$ & $0.294 \pm 0.002$ & 26.37 \\
\cline { 2 - 4 } & $75 \%$ & $0.291 \pm 0.001$ & 26.37 \\
\cline { 2 - 4 } & $100 \%$ & $0.281 \pm 0.001$ & 26.39 \\
\hline
\end{tabular}

Table 5: The color determination for biscuits prepared with different replacement of new barley flour varieties.

\begin{tabular}{|c|c|c|c|c|}
\hline \multicolumn{2}{|c|}{ Samples } & L(Lightness) & a (Redness/greenness) & b (Yellowness/blueness) \\
\hline \multicolumn{2}{|l|}{ Control } & $83.57^{a} \pm 0.11$ & $1.37^{\mathrm{e}} \pm 0.22$ & $34.98 a \pm 0.21$ \\
\hline \multirow[t]{4}{*}{ Giza 130} & $25 \%$ & $82.65^{\mathrm{ab}} \pm 0.23$ & $2.50^{\mathrm{d}} \pm 0.10$ & $30.57^{c} \pm 0.22$ \\
\hline & $50 \%$ & $80.42^{\text {cd }} \pm 0.11$ & $5.03^{\mathrm{b}} \pm 0.14$ & $30.96^{\mathrm{a}} \pm 0.11$ \\
\hline & $75 \%$ & $80.41^{\mathrm{cd}} \pm 0.23$ & $3.32^{\mathrm{cd}} \pm 0.11$ & $33.59^{\mathrm{ab}} \pm 0.23$ \\
\hline & $100 \%$ & $79.47^{\mathrm{ab}} \pm 0.11$ & $5.39^{b} \pm 0.23$ & $34.74^{\mathrm{c}} \pm 0.12$ \\
\hline \multirow[t]{4}{*}{ Giza 131} & $25 \%$ & $82.69^{\mathrm{ab}} \pm 0.22$ & $2.98^{\mathrm{d}} \pm 0.11$ & $30.52^{\mathrm{bc}} \pm 0.24$ \\
\hline & $50 \%$ & $81.21^{c} \pm 0.25$ & $2.56^{\mathrm{d}} \pm 0.25$ & $30.76^{c} \pm 0.11$ \\
\hline & $75 \%$ & $80.62^{\mathrm{e}} \pm 0.27$ & $4.04^{\mathrm{c}} \pm 0.23$ & $31.54^{\mathrm{c}} \pm 0.33$ \\
\hline & $100 \%$ & $76.70^{\mathrm{bc}} \pm 0.23$ & $4.18^{c} \pm 0.12$ & $32.21^{\mathrm{c}} \pm 0.14$ \\
\hline \multirow[t]{4}{*}{ Giza 135} & $25 \%$ & $82.55^{\mathrm{ab}} \pm 0.27$ & $3.21 c^{d} \pm 0.11$ & $33.42^{\mathrm{ab}} \pm 0.15$ \\
\hline & $50 \%$ & $79.58^{\text {cd }} \pm 0.23$ & $5.35^{b} \pm 0.15$ & $33.96^{\mathrm{a}} \pm 0.13$ \\
\hline & $75 \%$ & $78.62^{\mathrm{d}} \pm 0.28$ & $5.73^{\mathrm{b}} \pm 0.10$ & $34.10^{\mathrm{a}} \pm 0.11$ \\
\hline & $100 \%$ & $69.59^{f} \pm 0.29$ & $8.19^{\mathrm{a}} \pm 0.11$ & $35.01^{\mathrm{a}} \pm 0.10$ \\
\hline \multicolumn{2}{|c|}{ LSD } & 1.275 & 0.683 & 1.215 \\
\hline
\end{tabular}

L (lightness with $\mathrm{L}=100$ for lightness, and $\mathrm{L}=$ zero for darkness), a [(chromaticity on a green $(-)$ to red $(+)], \mathrm{b}$ [(chromaticity on a blue $(-)$ to yellow $(+)], 90^{\circ}=$ yellow, $180^{\circ}=$ bluish to green and $270^{\circ}=$ blue scale. .Values are mean of three replicates followed by \pm SD, the number in the same column followed by the same letter are not significantly different at 0.05 level . 
odor and texture with increasing the replacement. From sensorial results, it could be concluded that replacement naked barley flour varieties not had a appitability effect on the characteristics of biscuits which reduce the ability of consumption in most of sen- sorial characteristics. While, the taste, odor and texture of biscuits improved in $\mathrm{G} 135$ by replacement of naked barley increase. These results agree with those reported by Eissa., et al. [47], Hassan., et al. [37], Prodhan., et al. [48] and Maray., et al. [40].

Table 6: The sensorial properties of biscuits prepared with different substitution of naked barley flour varieties.

\begin{tabular}{|c|c|c|c|c|c|c|c|}
\hline \multicolumn{2}{|c|}{ Samples } & Color (20) & Appearance (20) & Texture (20) & Taste (20) & Odor (20) & Overall acceptability (100) \\
\hline \multicolumn{2}{|c|}{ Control } & $19.20^{\mathrm{a}} \pm 0.2$ & $19.20^{\mathrm{a}} \pm 0.5$ & $18.82^{\mathrm{a}} \pm 0.5$ & $19.34^{\mathrm{a}} \pm 0.2$ & $19.18^{\mathrm{a}} \pm 1.5$ & $95.74^{\mathrm{a}} \pm 1.2$ \\
\hline \multirow{4}{*}{$\begin{array}{l}\text { Giza } \\
130\end{array}$} & $25 \%$ & $18.80^{\mathrm{a}} \pm 1.1$ & $18.74^{a} \pm 0.3$ & $17.74^{\mathrm{ab}} \pm 0.2$ & $18.20^{\mathrm{a}} \pm 0.5$ & $18.20^{\mathrm{a}} \pm 2.0$ & $91.68^{\mathrm{abc}} \pm 2.5$ \\
\hline & $50 \%$ & $18.40^{\mathrm{a}} \pm 1.3$ & $18.14^{\mathrm{a}} \pm 0.2$ & $16.50^{\mathrm{ab}} \pm 0.1$ & $17.20^{\mathrm{a}} \pm 0.2$ & $18.00^{\mathrm{a}} \pm 1.3$ & $87.44^{\mathrm{abc}} \pm 2.3$ \\
\hline & $75 \%$ & $16.80^{\mathrm{ab}} \pm 1.5$ & $16.94^{\mathrm{a}} \pm 0.5$ & $16.00^{\mathrm{ab}} \pm 0.6$ & $17.00^{\mathrm{a}} \pm 0.4$ & $17.20^{\mathrm{a}} \pm 1.5$ & $82.94^{c} \pm 1.1$ \\
\hline & $100 \%$ & $16.20^{b} \pm 2.3$ & $16.80^{\mathrm{a}} \pm 0.3$ & $15.60^{\mathrm{b}} \pm 0.5$ & $17.00^{\mathrm{a}} \pm 0.2$ & $16.60^{\mathrm{a}} \pm 1.4$ & $84.00^{b c} \pm 5.5$ \\
\hline \multirow{4}{*}{$\begin{array}{l}\text { Giza } \\
131\end{array}$} & $25 \%$ & $19.00^{\mathrm{a}} \pm 0.2$ & $18.94^{\mathrm{a}} \pm 0.2$ & $18.60^{\mathrm{ab}} \pm 0.3$ & $19.30^{\mathrm{a}} \pm 0.1$ & $19.12^{\mathrm{a}} \pm 1.0$ & $94.96^{\mathrm{ab}} \pm 3.6$ \\
\hline & $50 \%$ & $18.92^{\mathrm{a}} \pm 1.2$ & $18.58^{\mathrm{a}} \pm 1.1$ & $18.24^{\mathrm{ab}} \pm 0.5$ & $18.92^{\mathrm{a}} \pm 0.2$ & $18.94^{\mathrm{a}} \pm 1.0$ & $93.60^{\mathrm{abc}} \pm 4.5$ \\
\hline & $75 \%$ & $18.34^{\mathrm{a}} \pm 1.1$ & $18.40^{\mathrm{a}} \pm 1.3$ & $17.78^{\mathrm{ab}} \pm 0.3$ & $17.82^{\mathrm{a}} \pm 0.5$ & $18.66^{a} \pm 1.5$ & $89.54^{\mathrm{abc}} \pm 4.5$ \\
\hline & $100 \%$ & $18.10^{\mathrm{ab}} \pm 0.2$ & $17.86^{\mathrm{a}} \pm 1.2$ & $17.10^{\mathrm{ab}} \pm 0.1$ & $17.72^{\mathrm{a}} \pm 0.3$ & $18.56^{a} \pm 1.6$ & $90.80^{\mathrm{abc}} \pm 2.3$ \\
\hline \multirow{4}{*}{$\begin{array}{l}\text { Giza } \\
135\end{array}$} & $25 \%$ & $18.20^{\mathrm{ab}} \pm 0.1$ & $18.30^{\mathrm{a}} \pm 1.1$ & $17.46^{\mathrm{ab}} \pm 0.2$ & $18.00^{\mathrm{a}} \pm 0.3$ & $18.20^{a} \pm 0.5$ & $91.50^{\mathrm{abc}} \pm 2.6$ \\
\hline & $50 \%$ & $18.20^{\mathrm{ab}} \pm 1.2$ & $18.10^{a} \pm 1.0$ & $17.50^{\mathrm{ab}} \pm 0.5$ & $18.20^{\mathrm{a}} \pm 0.4$ & $18.20^{\mathrm{a}} \pm 2.0$ & $90.00^{\mathrm{abc}} \pm 3.3$ \\
\hline & $75 \%$ & $17.40^{\mathrm{ab}} \pm 0.3$ & $17.00^{\mathrm{a}} \pm 0.1$ & $17.60^{\mathrm{ab}} \pm 0.2$ & $18.84^{\mathrm{a}} \pm 0.2$ & $18.70^{\mathrm{a}} \pm 1.9$ & $88.40^{\mathrm{abc}} \pm 4.4$ \\
\hline & $100 \%$ & $17.00^{\mathrm{ab}} \pm 0.1$ & $16.70^{\mathrm{a}} \pm 0.3$ & $18.40^{\mathrm{ab}} \pm 0.5$ & $19.10^{\mathrm{a}} \pm 0.2$ & $18.90^{\mathrm{a}} \pm 1.1$ & $90.10^{\mathrm{abc}} \pm 4.6$ \\
\hline \multicolumn{2}{|c|}{$\operatorname{LSD}(0.05)$} & 1.293 & 1.477 & 1.77 & 1.484 & 2.109 & 6.497 \\
\hline
\end{tabular}

\section{Conclusion}

The biscuits prepared by composite naked barley flour rich in nutrients than biscuits prepared with soft wheat flour. This showed that the naked barley flour is a good source of protein, ether extract, fiber and ash content. Hence it could be incorporated as nutritive ingredients in the production of healthy food products. Our results show the possibility of making good quality biscuit with naked barley and this is going to open a new market potential to an old cereal. Made biscuit from naked barley flour as a superior healthy and good acceptability, quality biscuit and reduce wheat flour shortages.

\section{Bibliography}

1. Baik A and S Ullrich. "A review on barley improvements, characteristics and its uses in cereal based food products". Journal of Cereal Science 21 (2008): 115-121.

2. Saulnier L. "Les grains decéréales: diversité et compositions nutritionnelles". Cahier de nutrition et diététiques 47 (2012): 54-515.

3. Mohamed Z., et al. "The Technological Quality of Barley Lines Selected from the First Cycle of Participatory Breeding in Algeria". The Journal of Agricultural and Crop Research (2018): 546-557.
4. Grando S and Gomez Macpherson H. "Food Barley: Importance, Uses and Local Knowledge". Proceedings of the- International Workshop on Food Barley Improvement Hammamet, Tunisia, 14-17 January (2002). ICARDA, Aleppo (Syria) (2005): 156..

5. El-Haramein FJ and Grando S. "Determination of iron and zinc content in food barley". In: Ceccarelli S and Grando S. Proceedings of the 10thInternational Barley Genetics Symposium, 5 - 10 April (2008), Alexandria, Egypt. Aleppo, Syria: International Center for Agricultural Research in the Dry Areas (ICARDA) (2010): 603-605.

6. FAO,(2010). FAO stat. database. Available from httb://faostat. fao.org.

7. Oscarsson M., et al. "Chemical composition of barley samples focusing on dietary fiber components". Journal of Cereal Science 16 (1996): 1-170.

8. Brennan CS and Cleary LJ. "The potential use of cereal (1-3, 1-4) - $\beta$-d-glucans as functional food ingredients". Journal of Cereal Science 42 (2005): 1-13.

9. Khatkar BS. "Trends in cereal processing". Beverage and Food World 32 (2005): 65-67.

10. EFSA. "Beta-glucans from oats and barley related health claims". EFSA Journal 9 (2011): 2207. 
11. Knuckles B E., et al. "Effect of $\alpha$-glucan barley fractions in high-fibre bread and pasta”. Cereal Foods World 42 (1997): 94-99.

12. Březinová Belcredi N., et al. "Barley grain as a source of health-beneficial substances". Czech Journal of Food Sciences 27 (2009): 242-244.

13. Keenan JM., et al. "The effects of concentrated barley -glucan on blood lipids in a population of hypercholesterolaemic men and women". British Journal of Nutrition 97 (2007): 1162-1168.

14. Spiller GA. "Handbook of Dietary fiber in human nutrition". 3rd edition. CRS press LLC.N.W. Corporate. Blvd. Boca. Rotan. Florida (2001): 363-365.

15. Izydorczyk MS and Dexter JE. "Barley $\beta$-glucans and arabinoxylans: Molecular structure, physico-chemical properties, and uses in food products A Review". Food Research International 41 (2008): 850-868.

16. Arshad U., et al. "Development and characterization of multigrain cookies". Pakistan Journal of Food Sciences 24 (2014): $1-5$.

17. Djurle S. "Carbohydrate quality of barley products with focus on $\beta$-glucan”. Doctoral thesis, Swedish University of Agricultural Sciences, Uppsala, Sweden (2017).

18. Škrbić B and Cvejanov J. "The enrichment of wheat cookies with high-oleic sunflower seed and hull-less barley flour: Impact on nutritional composition, content of heavy elements and physical properties". Food Chemistry 124 (2011): 14161422.

19. Pejcz E., et al. "Effect of naked barley enrichment on the quality and nutritional characteristics of bread - part i. the effect on wheat bread". Engineering Science and Technology 2 (2016): 38-45

20. Dabija A., et al. "Study on Flour Quality Assessment Designed to obtain Biscuits". Journal of Faculty of Food Engineering Stefan cel Mare University of Suceava Romania 14 (2015): 218-222.

21. Škrbić B., et al. "Effect of Hull-less barley flour and flakes on bread nutritional composition and sensory properties". Food Chemistry 115 (2009): 982-988.

22. Sudha ML., et al. "Influence of fiber from different cereals on the rheological characteristics of wheat flour dough and on biscuit quality". Food Chemistry 100 (2007): 1365-1370.

23. Lourencetti ER., et al. "Development of biscuit type cookie with partial replacement of fat by inulin". International Journal of Nutrition and Food Sciences 2 (2013): 261-265.
24. Čonova V and Karađov G. "Technology of Bakery and Confectionery Products". University of Food Technologies, Plovdiv, Bulgaria (2014)

25. Health Canada. Oat products and blood cholesterol lowering Summary of assessment of a health claim about oat products and blood cholesterol lowering (2010).

26. Gloria DL. "Determining Reference Test Weight per Bushel Value of Grains". Weights and Measures Connection 4.6 (2013): $1-4$.

27. A.A.C.C. American Association of Cereal Chemists. Published by American Association of Cereal Chemists, 10th Ed International St. paul, Minnesota, U.S.A (2010).

28. Heywood AA., et al. "Functional properties of low-fat soy flour produced by an extrusion-expelling system". Journal of the American Oil Chemists' Society 79 (2002): 1249-1253.

29. Traynham TL., et al. "Evaluation of water-holding capacity for wheat-soy flour blends". Journal of the American Oil Chemists' Society 84 (2007): 151-155.

30. Nidhina N and Muthukumar SP. "Antinutritional factors and functionality of proteinrich fractions of industrial guar meal as affected by heat processing". Food Chemistry 173 (2015) 920-926.

31. Piga A., et al. "Texture evaluation of Amaretti cookies during storage". European Food Research and Technology 221 (2005): 387-391.

32. Budžaki S., et al. "Influence of cookies composition on temperature profiles and qualitative parameters during baking". Croatian Journal of Food Science and Technology 6 (2014): 7278.

33. AOAC. "Association of Official of Analytical Chemists, Official Methods of Analysis". 19th Edition., Washington DC, USA (2010).

34. Smith WH. "Wine-cut cookies". In: Smith, W.H. (Ed.). Biscuit, crackers and cookies: Technology, Production and Management". Applied Science Pulishers London 737 (1972).

35. SAS. "Statistical analysis system". Release 6.03. SAS. Institute Inc. Carry, Nc. USA (1996).

36. Abdellatif AS. "A Chemical and technological evaluation of quinoa (Chenopodium quinoa Willd) Cultivated in Egypt". Acta Scientific Nutritional Health 2 (2018): 42-53.

37. Hassan AA., et al. "Production of Functional Biscuits for Lowering Blood Lipids". World Journal of Dairy and Food Sciences 7 (2012): 01-20. 
38. Lopez E P. “Influence of the addition of lupine protein isolate on the protein and techno-logical characteristics of dough and fresh bread with added Brea Gum". Food Science and Technology 34 (2014): 195-203.

39. Abdel-Gawad AS., et al. "Chemical Composition, Functional Properties and Antioxidant Activity". Assiut Journal of Agricultural Sciences 47 (2016): 430-442

40. Maray A R., et al. "Effect of the Partial Replacement of Wheat Flour with Barley Flour on Quality Attributes of Bread and Biscuits". Recent Advances in Food Science 1 (2018): 42-50.

41. Altschul M and AL Wilcke. "New protein food". Journal of Food Science and Technology F.L. Orlando, Academic Press (1985).

42. Aguilera Y., et al. "Starch, functional properties, and microstructural characteristics in chickpea and lentil as affected by thermal processing". Journal of Agricultural and Food Chemistry 57 (2009): 10682-10688.

43. Anonymous. "Official Methods of Analysis". (15th Edition), Association of Analytical Chemists, Washington, DC (1990).

44. Adeyeye EI and Aye PA. "The effect of sample preparation on proximate composition and the functional properties of African yam bean flours". Note 1 La Rivista Italiana Della Sostanze Grasse, LXXV-Maggio (1998): 253-261.

45. Helm C V., et al. "Hull-less barley varieties: storage proteins and amino acid distribution in relation to nutritional quality". Food Biotechnology 18 (2004): 327-341.

46. Akinyede AI and IA Amoo. "Chemical and functional properties of full fat and defatted Cassia fistula seed flours". Pakistan Journal of Nutrition 8 (2009): 765-769.

47. Eissa HA., et al. "Rheological properties and quality evaluation of Egyptian balady bread and biscuits supplemented with flours of ungerminated and germinated legume seeds or mushroom". Polish Journal of Food and Nutrition Sciences 57 (2007): 487-496.

48. Goldstein A., et al. "Effects of cellulosic fibre on physical and rheological properties of starch, gluten and wheat flour". International Journal of Food Science and Technology 45 (2010): 1641e1646.

Volume 3 Issue 11 November 2019

(C) All rights are reserved by Abdelazim SAA., et al. 